\title{
Erratum to: Dog bite injuries to humans and the use of breed-specific legislation: a comparison of bites from legislated and non-legislated dog breeds
}

\author{
Nanci Creedon ${ }^{1 *}$ and Páraic S. Ó Súilleabháin ${ }^{2}$
}

\section{Erratum}

After publication of the original article [1] it was brought to our attention that the following errors had occurred:

1. Author Páraic S. Ó Súilleabháin was incorrectly included as Páraic S. Ó'Súilleabháin. The correct spelling of the surname is included in the author list of this erratum and updated in the original article.

2. Furthermore, number 1 was omitted from Table 6 , question "In your experience, do you believe legislated dog breeds can inflict greater injuries or physical damage compared to non-legislated breeds of similar size?", response "Missing". The corrected table is provided here and has been updated in the original article.

\section{Author details}

'Department of Dog Behaviour, Creedons College, Vicars Road, Cork City, Ireland. ${ }^{2}$ School of Psychology, National University of Ireland, Galway,

University Road, Galway, Ireland.

Received: 3 August 2017 Accepted: 3 August 2017

Published online: 15 August 2017

\section{Reference}

1. Creedon N, Ó Súilleabháin PS. Dog bite injuries to humans and the use of breed-specific legislation: a comparison of bites from legislated and nonlegislated dog breeds. Ir Vet J. 2017;70:23. https://doi.org/10.1186/s13620017-0101-1.
Table 6 Sample sizes and incident percentages for dog control officer survey

\begin{tabular}{ll}
\hline & $\mathrm{n}(\%)^{\mathrm{a}}$ \\
\hline How is a dog's breed identified? & $5(29)$ \\
Officer visually identifies the breeds & $6(35)$ \\
Officer visually identifies the breeds and asks owner & $5(29)$ \\
Officer visually identifies, asks owner and checks records & $1(6)$ \\
Do not record breed &
\end{tabular}

Do you currently accept surrenders of legislated dog breeds from the public?

Yes

No

Missing

Do you allow the rehoming of legislated dog breeds?

Yes

15(94)

No (some breeds)

Missing

Do you believe breed specific legislation is effective in reducing dog bites in Ireland

In your experience, do you believe legislated dog breeds can inflict greater injuries or physical damage compared to non-legislated breeds of similar size?

In your experience, are legislated dog breeds more aggressive than non-legislated breeds?

* Correspondence: nancicreedon@creedonscollege.ie

${ }^{1}$ Department of Dog Behaviour, Creedons College, Vicars Road, Cork City, Ireland

Full list of author information is available at the end of the article 